\title{
THE EFFECT OF TRANSFORMATIONAL LEADERSHIP AND WORK CULTURE TO LECTURES' PERFORMANCE
}

\author{
Erwin Bakti \\ Muhammadiyah University of Palembang, \\ erwinbakti ump@yahoo.co.id
}

\begin{abstract}
The objective of this study was to find out the influence of transformational leadership and work culture on lecturer's performance of Universitas Muhammadiyah Palembang. This study used quantitative approach, survey method and path analysis. The data was taken from 204 lecturers and 29 heads of study program became the sample in this study. The result of the study found that (1) transformational leadership gave direct positive influence on the performance; (2) work culture gave direct positive influnce on lecturer's performance; and (3) transformational leadership gave direct positive influnce on work culture. Form the research has been conducted, it could be concluded there must be the improvement of transformational leadership and work culture to improve the lecturer's performance of Universitas Muhammadiyah Palembang.
\end{abstract}

Keywords:Transformational Leadership, Work Culture, lecture's Performance.

Higher education has a very important role in educating and improving the ability of Indonesian human resources. To produce qualified human resources required higher quality education as well. One of the factors that has an important role to produce qualified human resources in higher education is lecturers. Universities that have qualified lecturers will be able to utilize other educational resources to create quality lectures and ultimately the result of student learning will be better.

In the Law of the Republic of Indonesia No.12 of 2012 states that the main task of lecturers in universities is to carry out education and teaching, research, and community service, called Tri Darma Higher Education. Lecturers who can implement Tri DarmaPerguruanTinggi with the best can be said lecturer who has good performance.

According to Suprihanto in Makawimbang (1989) Performance is the result of work achieved by an employee during a certain period compared with various possibilities such as predefined standards, targets, objectives or criteria that have been predetermined and mutually agreed. With regard to lecturer performance, the opinion of Danim\&Kairil (2011) implies that a good lecturer is characterized by the following; have an awareness of purpose, have hope for success for all students, tolerate ambiguity, show willingness to adapt and change to meet student needs, feel uncomfortable if lacking know, reflect commitment to their work, learn from various models, enjoy their work and students.

The measure of performance can be expressed as performance indicators. According to Gomes (in Riani, 2011) performance indicators are as follows: (1) quantity of work, (2) quality of work, (3) knowledge of work, (4) creativity, (5) cooperation, (6) (7) initiative, (8) personal quality. For lecturer performance indicator in university muhammadiyah, it is necessary to refer to the guidance of Muhammadiyah Central Leadership Number: 02 / PED / 1.0 / B / 2012 about Muhammadiyah University which stated that Muhammadiyah university is obliged to perform chess dharma Muhammadiyah university that is education and teaching, research, community service and the development of Al-islam and Kemuhammadiyahan. Thus, performance indicators in this study are education and teaching, research and writing of scientific papers, community service and development of Al-Islam and Kemuhammadiyahan. 
Based on data from BAU and LPPM Muhammadiyah University of Palembang Year 2016 it is known that the performance of lecturers is still not optimal, it is seen from the data showing only $9.09 \%$ of lecturers who do textbook writing. So also in the field of research only $13.65 \%$ of lecturers who conduct research and in community service activities only $5.26 \%$ of lecturers who carry out community service activities. This is allegedly due to the application of transformational leadership that has not been strong and the low work culture of lecturers.

Allegations of transformational leadership factors affecting the low performance can be seen from several indicators, namely improving the quality of lecturers more on the personal effort of the lecturers concerned, less conducive learning environment, the leadership of the study program leader has not been strong, the attention and guidance of the leader of the lecturer in performing the task has not been maximized, there are still lecturers who lack discipline in performing the task and so forth. The problem arises because the leader can not perform his leadership function properly. While the working culture of lecturers at Muhammadiyah University of Palembang has not been good. This can be seen from the lecturer who is not working diligently in achieving the goal, there are still lecturers who are less active and creative in carrying out duties, fellow lecturers still occur discrepancies, there are still lecturers who pay less attention to the creativity of students, less provide good service to students and so on .

Yuki (2013) argues that if transformational leadership is regarded as effective in any situation or culture, there is a positive relationship between transformational leadership and the effectiveness imitated by many subordinates at different levels of authority, making it easier to improve performance. This theory is supported by the results of research from Susanto and Aisiyah (2010), with research conducted on leadership and work culture on employee performance in Kebumen District Defense Office where the results showed that leadership and work culture together have a positive and significant influence on employee performance at Kebumen District Defense Office.

Transformational leadership arises from the lack of a previous leadership model. The factors that influence transformational leadership become a dimension. Where the factors that arise are derived from a weakness or excess along with the components that exist. According to Wahjono (2010) the components of transformational leadership are (1) Idealized influence, (2) Inspirational motivation, (3) Intellectual stimulation, (4) Individualized consideration. Transformational leadership indicators in this study are work sincere, mature personality, consistent solve problems, and change the culture.

In addition to influencing performance, transformational leadership also makes its subordinates more aware of the importance of work culture values. This is consistent with that of Yuki (2013) that leaders develop employees' ability and confidence to prepare them to increase more responsibility in the work so that it will instill a better work culture. Khuzaeni, Idrus, Djumhari\&Solimun (2014) stated that culture significantly affects employee performance. A work culture that emphasizes the high productivity that employees work despite job satisfaction declines as evidence that job satisfaction improves performance because employees feel that the work they have done is bound by organizational rules is what needs to be done. Indicators of work culture in this research is perseverance, creative, mutual respect, cooperate, and able to adjust.

The purpose of this study is to determine the effect of transformational leadership and work culture on the performance of lecturers Muhammadiyah University of Palembang. This research is expected to provide three benefits namely, theoretical benefits, practical benefits and policy benefits. Theoretically, this research is expected to preserve and enrich the theory of performance, transformational leadership and work culture which are all part of the scope of education management science. In practical terms this research is useful for university leaders in order to foster lecturers to achieve high performance. For lecturers can be a reference in achieving high performance. For students will get a positive impact because it is taught by high achieving lecturers and led by qualified university leaders in terms of transformational leadership. As for policy makers, the results of this 
research are useful for one reference material for the government, especially the education policy makers in terms of performance improvement, leadership of the rector and the dean, creating a conducive working culture in the campus environment.

\section{METHOD}

This study uses quantitative, survey methods and path analysis techniques. Quantitative approach is used to analyze the effect of transformational leadership independent variables (X1) and work culture (X2) on lecturer performance dependent variable (Y). Data obtained through survey methods were analyzed using inferential statistics with path analysis techniques.

The population of this research is permanent lecturer of Muhammadiyah University of Palembang spread in 7 faculties and 29 study programs amounting to 418 people. While the number of samples in this study was calculated based on the Slovin formula and obtained a sample of 204 lecturers. The number of samples of each study program is determined based on the proportion of the number of lecturers present in the study program and the lecturers used as the sample of the study were randomly selected by using the lottery.

Data collection techniques used in this study is a field survey by distributing questionnaires to lecturer respondents who used as sample research. The questionnaire provided is based on the indicators of each variable studied and has been tested for its validity and reliability.

After the data collected, the data were analyzed using path analysis technique with the help of SPSS V.22.0 for windows. Path analysis technique is used to know the total influence and the direct influence of transformational leadership variable and work culture on the performance of lecturer of Muhammadiyah University of Palembang.

\section{DISCUSSION}

The results of this study are described in three parts: 1) description of data from each variable by size and distribution; 2) the result of prerequisite test analysis to be used as a basis in determining the technique of data analysis; 3) the results of hypothesis testing and data analysis to explain empirically the relationship between research variables. The sample in this study amounted to 204 permanent lecturers at Muhammadiyah University of Palembang by using proportional random sampling method. A total of 204 questionnaires were given and distributed randomly to lecturers for each course at the Muhammadiyah University of Palembang. Based on the results of the distribution of questionnaires, it turns out that as many as 4 questionnaires can not be processed because the respondents did not fill with a complete and decent processed there are as many as 200 questionnaires.

Based on the results of questionnaires for each variable found that from 28 points statement obtained average value for the performance variable of 111.13 means that the performance of permanent lecturers at the University of Muhammadiyah Palembang is quite optimal, although there are still lecturers who have relatively low performance. The transformational leadership variable has 24 points of statement and obtained an average value of 98.95. This means that the transformational leadership felt by the lecturers remains strong enough, although there are still permanent lecturers who judge is still relatively poor. Work culture variable has 26 point statement and obtained average value equal to 104,63. This means that the work culture of permanent lecturers at the muhammadiyahuniversity of palembang is strong enough to be planted.

Prior to hypothesis testing, the data that has been obtained needs to be tested prerequisites. The prerequisite test performed is the normality test of regression error data, as well as the significance and regression linearity test. Normality testing was performed on all six regression estimates of the study. This normality test uses the Liliefors test with the help of Ms. Excel. Result of normality test of error Y over X1 obtained L0 equal to 0,0538 , whereas result of error test of $\mathrm{Y}$ for $\mathrm{X} 2$ is obtained L0 equal to 0,0421 , and result of error test of X2 $\mathrm{x} 1$ on X1 obtained L0 equal to 0,0307 . Based on these results when compared with the value of alpha $(\alpha)$ of 0.05 then the value of 
L0 for each error is smaller than the alpha value. It can be concluded that all the estimates are normally distributed so as to satisfy the normality assumption.

Then tested the significance and regression linearity to the regression model that has been obtained. Result of significance siginifikansi Y test on X1 obtained value of Fcount equal to 98,571, result of significance test of variable $\mathrm{Y}$ over X2 obtained value Fhitung equal to 18,801, and result of significance test of $\mathrm{X} 2$ on $\mathrm{X} 1$ obtained Fcount 4,656. If the result is compared with the Ftable value for the $\alpha$ value of 0.05 ie 3.888 , it can be concluded that the data satisfy the significance test because the Fcount value is greater than the Ftable value.

Result of regression linearity test of variable Y over X1 obtained value Fhitung equal to 1,202. Result of significance test of variable Y over X2 obtained value Fhitung equal to 0,993, and result of significance test of X2 variable over X1 obtained Fhitung equal to 1,299. If the result is compared with the Ftable value for the $\alpha$ value of 0.05 ie 1.463 , it can be concluded that the data satisfies the linearity test because the Fcount value is less than the Ftable value. Because the data obtained meets all the prerequisite tests, it is followed by hypothesis testing between transformational leadership variables (X1), work culture (X2), and performance (Y) with path analysis technique.

Based on the results of testing of path analysis techniques using SPSS 22.0 obtained by the value of determination coefficient R2 of 0.361 so that the value

$$
\rho_{3} \varepsilon_{2}=\sqrt{1-R^{2}}=\sqrt{1-0,361}=0,799
$$

Table 1.Results of SPSS Second Substructure Model

\begin{tabular}{|c|l|c|c|c|c|c|}
\hline \multicolumn{2}{|c|}{ Model } & \multicolumn{2}{|c|}{$\begin{array}{c}\text { Unstandardized } \\
\text { coefficients }\end{array}$} & $\begin{array}{c}\text { Standardized } \\
\text { Coefficients }\end{array}$ & \multirow{2}{*}{ t } & \multirow{2}{*}{ Sig. } \\
\cline { 3 - 5 } \multicolumn{2}{|c|}{} & B & Std. Error & Beta & & \\
\hline \multirow{2}{*}{1} & (Constant) & 23,613 & 8,700 & & 2,714 &, 007 \\
& X1 &, 647 &, 070 &, 530 & 9,197 &, 000 \\
& X2 &, 225 &, 060 &, 214 & 3,717 &, 000 \\
\hline
\end{tabular}

From Table 1 we get the equation model $\mathrm{Y}=0,530 \mathrm{X} 1+0,214 \mathrm{X} 2+0,799$. Based on the equation can be concluded that respectively, among the two variables that have the most influence on performance is Transformational Leadership variable with regression coefficient of 0.647 , and followed by work culture variables with regression coefficient of 0.225 . While the magnitude of correlation coefficient of transformational leadership (X1) to performance (Y) is 0,562 and the magnitude of work culture correlation coefficient (X2) to performance $(\mathrm{Y})$ is 0,562 .

Criteria of correlation coefficient between variables disclosed by Sugiyono (2014) is known if the correlation coefficient value between $0,000-0.199$ then has a very low correlation, if the value of correlation coefficient between $0.200-0.399$ then has a low correlation, if the value of correlation coefficient between $0.400-0.599$ then has the correlation is, if the correlation coefficient value between $0.600-0.799$ then has a strong correlation, and if the correlation coefficient value between $0.800-1,000$ then has a very strong correlation. Based on these criteria, it can be seen that the correlation between transformational leadership variables (X1) on performance (Y) is in the medium category. Thus, it can be concluded that there is a positive direct influence between transformational leadership and performance. While the correlation between work culture variables (X2) on performance $(\mathrm{Y})$ is in the low category. Nevertheless, it can be concluded that there is a positive direct effect between work culture and performance.

The result of hypothesis testing shows that transformational leadership variable Ka.Prodi directly positive effect on the performance of lecturers. This means that if the transformational leadership of Ka. Prodi positive then the lecturer's performance will increase (high). The results are in line with the opinions of some experts such as Colquit,Lepine\& Wesson (2015) said the 
transformational leadership of the head of the study program can affect the performance of lecturers. Lecturers led by heads of courses with transformational leadership tend to perform better.

Further research results Vigoda-Gadot (2007) also revealed that there is a close relationship with transformational leadership performance. This is because this type of leadership shapes the perception that the leadership style is fair, upholds equality and is very little influenced by the things that are political. The results of research conducted by Mubarak and Darmanto (2015) which shows that the leadership style of transformational have a positive and significant impact on employee performance. So the better the leadership style of transformational superiors will have an impact on employee performance is getting better.

Leaders who are responsible for the progress of an institution, it is because the leader has the authority and duty. Deploy subordinates (lecturers and staff). Leaders should be able to mobilize subordinates to work together as a team to achieve the goals of the institution. A Ka. Prodi as a leader must be able to inspire lecturers to work better. Based on the description, it can be concluded that the transformational leadership of the head of the study program is one of the determining factors in improving the performance of lecturers.

Furthermore, the results of the hypothesis testing analysis also shows that cultural variables have a positive direct effect on performance. This means that if the work culture goes well then it can improve the lecturer's performance. This result is similar to the opinion of Neslon and Quick (2005) which states that an organization with a strong culture will lead to better performance than others. A strong culture is an organizational culture with consensus about values that drive the organization and its intensity that is recognized even for outsiders, thus a strong culture is shared. Based on the description, the work culture is one of the decisive factors in improving the performance of lecturers.

\section{CONCLUSION}

Based on the results of statistical tests and hypotheses and discussions that have been done, it can be obtained the conclusion of some things as follows. (1) there is a positive and significant influence of transformational leadership and work culture on the performance of lecturers of Muhammadiyah University of Palembang. (2) there is a positive and significant influence of transformational leadership on the working culture of lecturers of Muhammadiyah University of Palembang. (3) there is a positive and significant influence of transformational leadership on the performance of lecturers of Muhammadiyah University of Palembang. (4) there is a positive and significant influence of work culture on the performance of lecturers of Muhammadiyah University of Palembang.

Based on the results of these discussions and conclusions, it can be submitted some suggestions as follows. The transformational leadership of the head of the study program within the Muhammadiyah University of Palembang needs to be improved by (a) the order of election and stipulation of the head of Muhammadiyah University Muhammadiyah environment study program needs to be updated and adapted to the needs and development of higher education; Prodi both academic ability and ability to lead the training periodically. (c) there is continuous monitoring by faculty leaders, (d) Ka. Prodi has a strong commitment to advance the study program and (e) providing adequate incentives.

In addition, the working culture of lecturers within Muhammadiyah University of Palembang needs to be improved through: (a) lecturers always work diligently for the progress of study program and faculty, (b) lecturers have creative ideas to answer the challenges and problems that arise (d) lecturer is expected to cooperate with other lecturers in implementing chess dharma college muhamamdiyah, and (e) lecturers can always adapt to the environment to create a harmonious working atmosphere. 


\section{REFERENCES}

Colquitt, J.A, Lepine, J.A, \& Wesson, M.J. (2015).Organization Behavior. Texas: McGraw Hill. Danim, SudarwandanKairil. (2011). PsikologiPendidikan (dalamperspektifBaru). Bandung: Alfabeta. Khuzaeni,MS., Idrus, Djumhari\&Solimun. (2014).The Role of integrity as A Mediator Between Work Satisfaction and Work Permormance in the Perspective of Islam: An EmpriCAL Approach Using Sem/Amos Model. International Journal Research in Applied 2(1).

Mikawimbang, J.H. (1989). KepemimpinanPendidikan yang Bermutu. Bandung: Alfabeta.

Mubarak, Ahmad danDarmanto,

Sustyo.(2015).

PengaruhKepemimpinanTransformasionaldanBudayaOraganisasiTerhadapKinerjaPegawai denganKomitmenOrganisasiSebagaiVariabel Intervening.JurnalMaksimumVol 5 No. 1.

Nelson, D.L dan Quick, J.C. (2005).Understanding Organizational Behavior.Ohio: South-western.

Riani, Laksmi. (2011). BudayaOrganisasi. Yogyakarta: Grahallmu.

Sugiyono. (2014). MetodepenelitianManajemen.Cetakan ke-3. Bandung: Alfabeta.

Susanto, HeridanAisyah, Nuraini.

(2010). AnalisisPengaruhKepemimpinandanBudayaKerjadenganMotivasisebagaiVariabel Intervening terhadapKinerjakaryawan di kantorPertahananKabupatenKebumen. JurnalMagistra No. 74 Th. XXII.

Vigoda-Gadot, E. (2007). Leadership Style, Oragizational Politics, and Employees' performance: An Emperical Examination of Two Competing Models. Personnel Review Vol. 36. No. 5.

Wahjono, S.I. (2010). PerilakuOrganisasi. Yogyakarta: Grahallmu.

Yuki, Gary. (2013). Leadership in Organization 8th Edition.England: Pearson. 